\title{
Financial Elements in Teaching and Learning of Mathematics: A Systematic Review
}

\author{
Noor Shazreen Amalin Saini \\ Faculty of Education, The National University of Malaysia \\ E-mail: p98131@siswa.ukm.edu.my \\ Roslinda Rosli (Corresponding author) \\ Faculty of Education, The National University of Malaysia \\ E-mail: roslinda@ukm.edu.my
}

Received: December 1, 2020

Accepted: January 6, 2021 Published: January 8, 2021

doi: 10.5296/ire.v9i1.18033

URL: https://doi.org/10.5296/ire.v9i1.18033

\begin{abstract}
Financial literacy is one of the 21 st-century skills that are important for young people. Thus, integrating financial components in Mathematics subject is a way to instill financial literacy among students. This study aimed to determine the factor influencing the integration of financial elements and identify effective methods to enhance students' financial literacy. The research articles are collected from 2011 until 2019 through online databases known as Education Resources Information Center (ERIC), Sage Journals, Web of Science (WOS), ScienceDirect, and SCOPUS. The research finding shows that the factors affecting students' financial literacy were teaching methods and strategies, parental socialization, and school curriculum. It is essential to understand the influence of numerous factors. Knowing the factors that lead to or detract from the acquisition of financial literacy among students will improve their economic well-being by making policy initiatives. Financial socialization such as learning in school and parents' involvement has become a significant factor in students' financial literacy. The practical methods used to enhance students' financial literacy consist of inquiry-based mathematics, technological simulation, interactive module, simulation games, workshops, and school camps.
\end{abstract}

Keywords: Financial literacy, Mathematics, School-based financial education, Financial mathematics, Systematics review 


\section{Introduction}

The aftermath of the global financial crisis, which began in 2007 until 2009, is a wake-up call for policymakers and other stakeholders to step up to the plate on improving financial literacy and financial well-being of individuals and society. Therefore, financial literacy education demands have risen significantly (Goyal \& Kumar, 2020; Mcgregor, 2016; Soroko, 2020). The recent events involving the outbreak of COVID-19 have been a harsh reminder of financial literacy's importance as every individual and nation faces severe financial challenges and economic downturns. On the other hand, cashless services and financial products accessible through digital platforms have also stressed the importance of financial management because most developed countries carry out online services that save time and costs. Along with the rapid changing of the economic landscape, everyone is responsible for their financial planning and management throughout their lifetime.

In Malaysia, the need for financial literacy in society is very critical. According to the Credit Counselling and Debt Management Agency (AKPK) survey in 2018, one out of three Malaysians is uncomfortable with their financial knowledge. More than $50 \%$ of Malaysians are having difficulties in raising even RM1,000 for emergencies. The current high consumer indebtedness level indicates a growing need for better financial management understanding among Malaysians (Mokhtar, Thinagaran, Sabri, \& Ho, 2018). Several studies have found a moderate financial literacy level, especially among youth (Aladdin \& Ahmad, 2017; Sawandi, Abu Bakar, Shaari, Saad, \& Amran, 2018; Yakob, Janor, \& Khamis, 2015). As financial products and services are increasingly complex and diverse, youth need to take risks and take greater responsibility for any decisions they make. Hence, it is necessary for us, as a customer, to be empowered and make the right financial decision.

Financial literacy should start at an early age. Children learn about money through informal and formal experiences, which means that financial literacy begins at home when children naturally observe or learn about money from their parents. The Organisation for Economic Co-operation and Development (2013) claims that the inclusion of financial education in the school curriculum is an effective and widely accessible way for an entire youth generation. In Malaysia, the Ministry of Education (MOE) unveils a national strategy to boost financial literacy by including financial elements in learning mathematics and other national curriculum subjects known as Standard-Based Primary School Curriculum (KSSR) and revised KSSR in 2017. Financial education is also integrated into many subjects at the secondary school level, such as Economic, Business Studies, and Principal of Account through Standard-Based Secondary School Curriculum (KSSM).

Basic financial literacy is commonly related to mathematical skills (Erner, Goedde-Menke, \& Oberste, 2016). However, many students could not apply numerical knowledge in financial computations despite having a good result in mathematics (Jayaraman \& Jambunathan, 2018). By integrating financial elements into mathematics lessons, students would have the opportunity to explore real-life financial situations through the lens of mathematics. However, to achieve successful financial literacy goals, implementing meaningful financial education in mathematics lessons will be challenging for teachers, especially when using different 
teaching methods. Hence, this study is carried out to synthesize academic research on integrating financial elements in mathematics instruction to answer these two research questions:

a) What factors influence students' financial literacy?

b) What is the effective method to enhance student's financial literacy?

\section{Literature Review}

\subsection{Financial Literacy}

Financial literacy is a broad and complex concept. Huston (2010) states that financial literacy should be conceptualized as having two dimensions: personal financial knowledge and finance application. Besides, financial literacy was described by OECD (2013) as follows:

Knowledge and understanding of financial concepts and risks, and the skills, motivation and confidence to apply such knowledge and understanding in order to make effective decisions across a range of financial contexts, to improve the financial well-being of individuals and society, and to enable participation in economic life (p. 144).

The OECD's definition highlighted the three standard comprehensive financial literacy dimensions: financial knowledge, economic behavior, and financial attitude. Meanwhile, Atkinson and Messy (2012) state that financial literacy is a combination of awareness, knowledge, skill, attitude, and behavior needed to make sound financial decisions and eventually achieve individual financial well-being. It is a significant component in understanding finances and making smart financial decisions (Swiecka, Yeşildağ, Özen, \& Grima, 2020). Policymakers and other stakeholders must resolve effective financial education to sustain a healthier financial literacy of individuals and society in the future. In recent years, many countries have started the ball rolling by providing financial education in schools, universities, and workplaces. OECD (2005) also has defined financial education as:

Financial education is the process by which financial consumers or investors improve their understanding of financial products, concepts and risks and through information, instruction and/or objective advice, develop the skills and confidence to become more aware of financial risks and opportunities, to make informed choices, to know where to go for help, and to take other effective actions to improve their economic well-being. (p. 13)

Based on the detailed definition, a clear distinction exists between financial literacy and financial education. Kaiser and Menkhoff (2017) discovered in a recent meta-analysis of 126 impact assessment studies that financial education significantly influences financial behavior and financial literacy. Moreover, Peeters, Rijk, Soetens, Storms, and Herman (2018) assert that motivation appears to be an essential condition to benefit from financial education and integrating financial elements with practical activities that allow learners to apply the skills they learn.

\subsection{Importance of Financial Literacy}

Based on the Malaysia Economic Monitor report published by World Bank in December 
2019 , it is estimated that a total of 60 percent of all bankrupt individuals in Malaysia are from millennials, which refers to young people between 25 until 44 years old due to the excessive expenses (Berita Harian, 2019). It also stated that this group was declared bankrupt because of the personal loan factor unrelated to investment, the accumulation of assets, failure to pay the vehicle loan, and credit card usage. In relation, lack of knowledge and poor management skills in finances will result in rising bankruptcy rates. Thus, the Insolvency Department, the Malaysian Financial Planning Council (MFPC), and the Credit Counselling and Debt Management Agency (AKPK) have organized various outreach programs to promote financial management awareness.

Moreover, significant financial education in school plays a vital role in enhancing youths' financial literacy before entering professional careers. A few studies show that students at the school level were barely exposed to financial knowledge, which influences their low financial literacy level (Garg \& Singh, 2018; Ghazali, Azer, Mohamad, Muhamad Arifin, \& Mat, 2017; Magesvari, Kenayathulla, \& Ghani, 2018). Generally, school students are not involved in financial issues until they reach adulthood. Still, they should have a sense of awareness, understanding, and confidence to ask the right questions regarding finances. For example, students should learn the value of their parents' pocket money and distinguish between wants and needs. Based on the study conducted by Wahab, Sabri, and Ramli (2016), showed that the spending and buying habits of primary school students in Malaysia need to be improving for the better. Even though financial knowledge can be accessed easily through the Internet, parents' involvement is necessary, and teachers or elders in their families should guide the young generation.

\subsection{Financial Literacy in Mathematics}

In most countries, integrating financial elements into the curriculum demonstrates that the content of learning standards does not concentrate on a specific field or subject. This method uses an interdisciplinary approach as it uses various areas to solve problems regarding financial literacy. As most problems involve a level of mathematics, there is a need for mathematics education to engage students in financial problem-solving experiences that will lead them to be critically knowledgeable in making decisions (Sawatzki, 2017a). According to Programme for International Student Assessment's result in 2015, 45\% of countries that show excellency in Mathematics are situated at the highest position in the financial literacy list with a correlation point of 0.74 (OECD, 2017). The high positive value indicates that there is a strong relationship between financial literacy and mathematics among students.

Furthermore, Ferreira and Bisognin (2020) state several benefits can be achieved through financial and daily problems. For example, increasing students' motivation in studying mathematics enables them to use mathematical concepts to plan or organize their spending habits and enhance their quality of life in a mindful, responsible, and independent manner. Crawford-Ferre, Wiest, and Vega (2016) have suggested a few financial literacy tasks can be implemented in the classroom to master the topics such as comparing similar goods or services, planning a budget, and figure out the costs of high education. Mathematical skills such as reasoning, constructing graphs, usage of number bases, and ratios or percentage can 


\section{Macrothink}

be applied in financial tasks or assessments. Therefore, the teachers' role is essential in helping the students to become responsible adults in managing their money by providing a realistic experience through mathematics lessons.

\section{Methodology}

The research is done systematically by identifying the evidence through the empirical method in line with the inclusive criteria set to answer the specific research questions or hypotheses (Snyder, 2019). This review was carried out according to the five stages of systematic literature review adapted from Khan, Kunz, Kleijnen, and Antes (2003) and use the PRISMA statement for reporting systematic reviews guidelines by Moher, Liberati, Tetzlaff, and Altman (2009). The steps are illustrated in Figure 1 below:

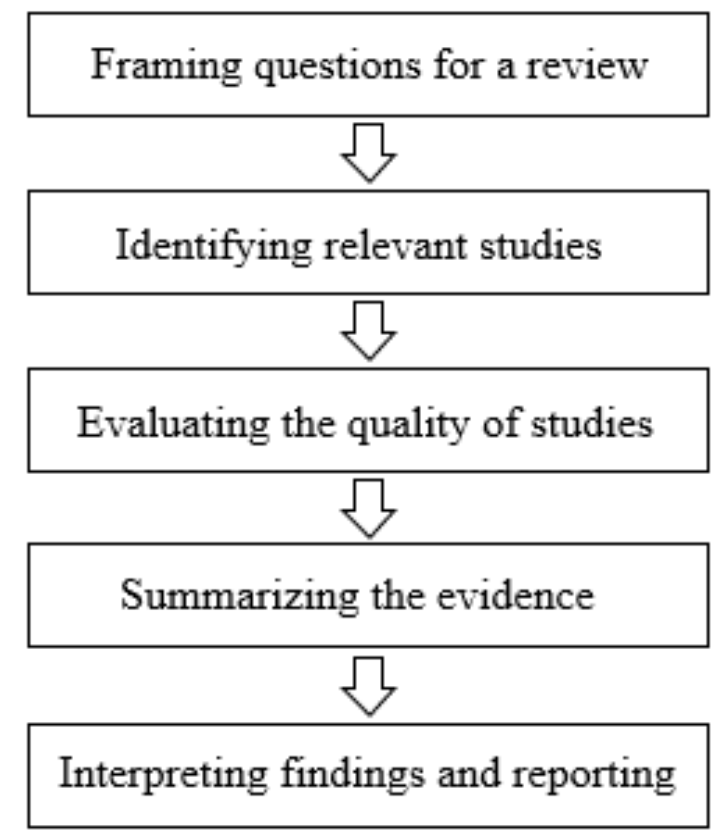

Figure 1. Stages of systematic literature review

\subsection{Framing the Questions}

The aim and research questions were identified through this stage to determine the research scope based on the selected data. The chosen empirical research is based on the factors influencing students' financial literacy at the school level, either from primary and secondary school, and suitable financial education approaches to be implemented among school students.

\subsection{Identifying Relevant Studies}

The setting up of the criteria to identify relevant studies involves two processes where: a) the search of articles is carried out using five online databases which are known as Web of Science (WOS), Education Resources Information Center (ERIC), SAGE Journals, 


\section{Macrothink

ScienceDirect, and SCOPUS; and b) selection of articles in the initial search are accompanied by guidelines for inclusion and exclusion in this study. The following keywords were applied in this search: "financial literacy" AND mathematics, "financial education in schools", and "financial literacy education". Furthermore, the search process for relevant articles is limited to the empirical research published from 2011 until 2019, using English and scholarly peer-reviewed publications.

\subsection{Evaluating the Quality of Studies}

The selection and review of the article are based on the inclusion and exclusion criteria in this research. The requirements that must be ruled out during this review process are dissertation, research action, theoretical paper, books, and systematic literature review. The empirical research is chosen because the data obtained depends on the direct observation or experiment and provide concrete evidence. Therefore, quantitative or qualitative research would be selected during the review process and involving school students. Since these studies were conducted overseas, thus the term "high school", "secondary school", "elementary school", and "primary school" become the inclusion in the data analysis. However, if the research does not involve school students, then the research was excluded. Finally, the most crucial aspect was the studies needed to explicitly explain their results, as the researchers had to interpret the findings according to preliminary questions.

Hence, the keyword in the selection process and review of the article used to collect the research articles to study the factors that influence financial literacy and determine effective financial education approaches. In the beginning, 714 research articles were screened according to the criteria, which were peer-reviewed and using the English language. The number of articles was reduced to 526 due to the redundancy research record in the excluded database. Then, a total of 46 papers were screened for not referring to school students. Lastly, a total number of 30 articles were collected and meet the criteria created by the researcher compared to 714 articles in the initial selection process. Figure 2 displays the PRISMA flow chart, which summarizes the details in the third stage of the research methodology. 


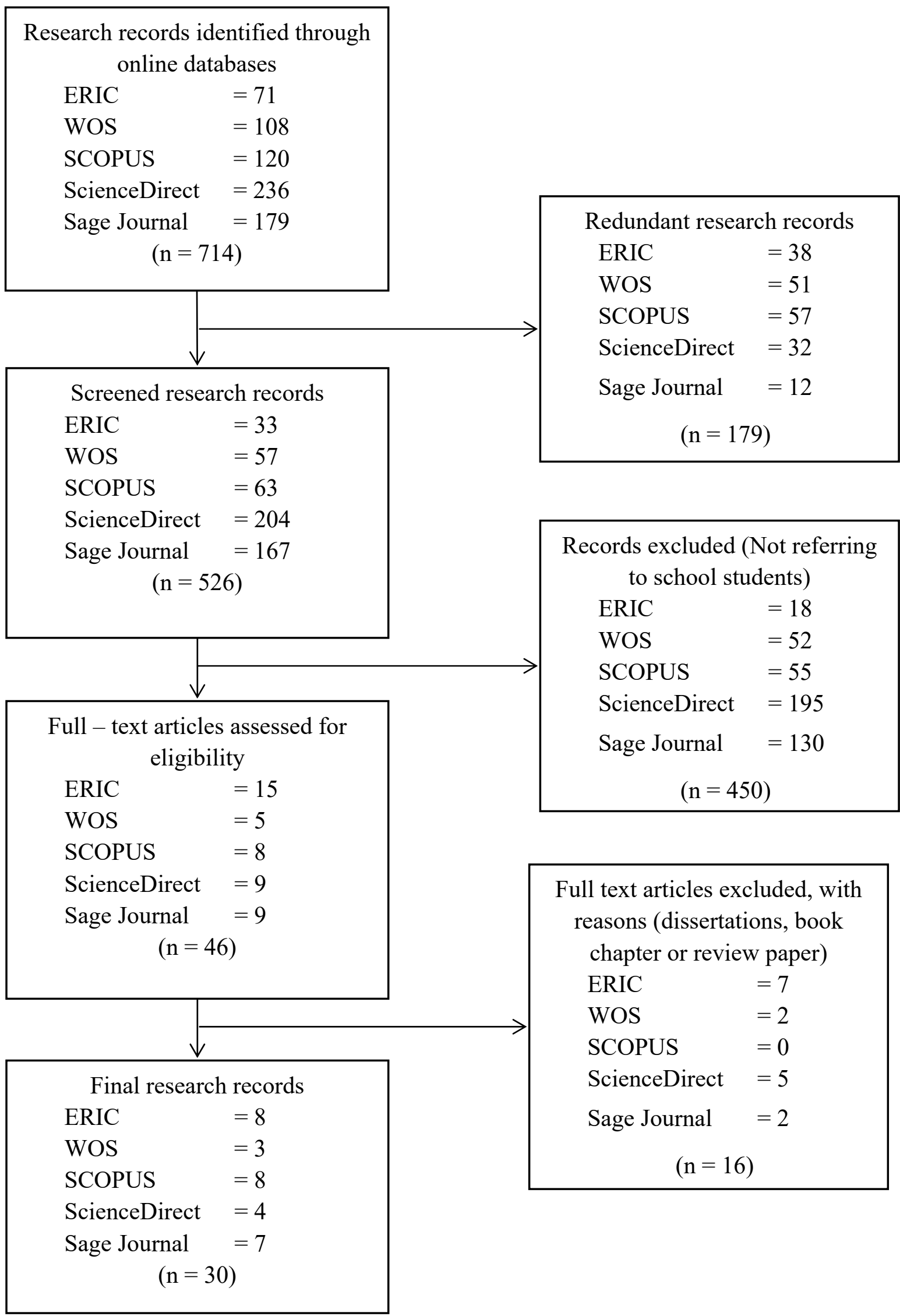

Figure 2. PRISMA Flow Chart 


\subsection{Summarizing the Evidence}

This research is conducted to collect any studies that examined the factors influencing students' financial literacy and recognize learning strategies to enhance students' financial literacy. According to Khan et al. (2003), the fourth stage includes a process where all information was systematically synthesized and tabulating the characteristics, quality, and outcomes from selected research articles. Thus, the synthesis matrix using Microsoft Excel was used to sort articles by themes or categories. It also helps to visualize ways that the core ideas are connected. According to the group of instruments, population, and research samples, the synthesis matrix emphasizes how the data is extracted and analyzed according to the suitable statistics based on the data collection method (Darusalam \& Hussin, 2018).

\subsection{Interpreting Findings and Reporting}

All 30 research articles are classified into two groups based on the research questions; most of the studies utilized quantitative analysis. Figure 2 shows PRISMA's flow chart; there are ten articles of qualitative research articles, 12 quantitative studies, and eight mixed research methods. Thirteen studies from 30 articles explored the factors influencing students' financial literacy, and 16 studies examined how to increase financial literacy among students. Moreover, one of the 30 articles studied both aspects. Based on the information analysis in Table 1, research question 1 refers to the factors influencing the students' financial literacy, while research question 2 refers to suitable financial education approaches.

Table 1. Number of studies based on research questions and methods

\begin{tabular}{llll}
\hline Methods & Research Question 1 & Research Question 2 & Both Research Questions \\
\hline Quantitative & 8 & 4 & 0 \\
Qualitative & 2 & 8 & 0 \\
Mixed-Method & 3 & 4 & 1 \\
\hline
\end{tabular}

\section{Findings}

\subsection{Factors that Influence the Students' Financial Literacy}

This research is based on the synthesis of information that influences the students' financial literacy and will be discussed in this section. Each study was classified into three categories of methodologies based on the research questions: a) Quantitative research, b) Qualitative research, and c) Mixed method research. Table 2 shows the list of research that studied the factors that influence the students' financial literacy. 
Table 2. List of studies on factors that influence financial literacy

\begin{tabular}{|c|c|c|c|c|}
\hline \multirow{2}{*}{\multicolumn{2}{|c|}{ Types of Factors }} & \multicolumn{3}{|l|}{ Methods } \\
\hline & & $\begin{array}{l}\text { Quantitative } \\
\text { research, } n=8\end{array}$ & $\begin{array}{l}\text { Qualitative } \\
\text { research, } n=2\end{array}$ & $\begin{array}{l}\text { Mixed method } \\
\text { research, } n=4\end{array}$ \\
\hline \multirow{2}{*}{\multicolumn{2}{|c|}{$\begin{array}{l}\text { Parental } \\
\text { socialization }\end{array}$}} & $\begin{array}{l}\text { Chambers, Asarta, } \\
\& \quad \text { Farley-ripple } \\
(2019)\end{array}$ & $\begin{array}{l}\text { Puspitarona, } \\
\text { Abdulhak, } \\
\text { Rusman (2019) }\end{array}$ & \\
\hline & & $\begin{array}{l}\text { Silva, Magro, Gorla, } \\
\text { \& Nakamura (2017) }\end{array}$ & & \\
\hline \multirow{2}{*}{$\begin{array}{l}\text { Practices } \\
\text { Methods } \\
\text { Teaching }\end{array}$} & \multirow{2}{*}{$\begin{array}{l}\& \\
\text { of }\end{array}$} & $\begin{array}{l}\text { Berková \& Krpálek } \\
\text { (2017) }\end{array}$ & & Opletalová (2017) \\
\hline & & & & $\begin{array}{l}\text { Belás, Nguyen, } \\
\text { Smrčka, Kolembus, } \\
\text { \& Cipovová (2016) }\end{array}$ \\
\hline \multirow{2}{*}{$\begin{array}{l}\text { Consumer } \\
\text { Socialisation } \\
\text { Financial } \\
\text { Experience }\end{array}$} & \multirow[b]{2}{*}{$\&$} & $\begin{array}{l}\text { Lahav, Shavit, \& } \\
\text { Benzion (2017) }\end{array}$ & & $\begin{array}{l}\text { Sawatzki \& Goos } \\
(2018)\end{array}$ \\
\hline & & $\begin{array}{l}\text { Moreno-García, } \\
\text { García-Santillán, \& } \\
\text { Gutiérrez (2019) }\end{array}$ & & \\
\hline $\begin{array}{l}\text { Student Ability } \\
\text { Student } \\
\text { Characteristics }\end{array}$ & $\&$ & $\begin{array}{l}\text { Cameron, } \\
\text { Calderwood, Cox, } \\
\text { Lim, \& Yamaoka } \\
(2013)\end{array}$ & & Sawatzki (2017b) \\
\hline \multirow{2}{*}{\multicolumn{2}{|c|}{ School curriculum }} & Opletalová (2015) & $\begin{array}{l}\text { Solomon, Nhete, \& } \\
\text { Sithole (2018) }\end{array}$ & \\
\hline & & $\begin{array}{ll}\text { Mahmudi } & \& \\
\text { Listiyani (2019) } & \end{array}$ & & \\
\hline
\end{tabular}

Overall, it is evident that most of the research used a quantitative method to investigate the factors that influence the students' financial literacy. The analysis of information consists of the studies that have the first research question or both research questions. Generally, the level of financial literacy among students is low (Belás et al., 2016; Berková \& Krpálek, 2017; Cameron et al., 2013) and needs to be improved (Opletalová, 2015). The findings showed several factors that affected students' financial literacy. For instances teaching methods (Belás et al., 2016; Opletalová, 2017; Sawatzki, 2017b), parental socialization (Chambers, Asarta, \& 
Farley-Ripple, 2019; Hamilton, Shobe, Murphy-Erby, \& Christy, 2012; Puspitarona et al., 2019; Silva et al., 2017) and school curriculum (Opletalová, 2015; Solomon et al., 2018). Besides, we found lack of engagement activities involved financial skills (Berková \& Krpálek, 2017; Lahav et al., 2017; Mahmudi \& Listiyani, 2019) lead to low economic competence among students (Sawatzki, 2017b). Cameron et al. (2013) compare Japanese students' overall performance, which was higher than the U.S. and New Zealand students. Even though Japanese students have poor comprehension and ability to apply the theory, the main advantage understood financial terms and definitions. These factors impact students' financial literacy, including financial attitude, financial knowledge, and support.

\subsection{Effective Methods to Enhance the Student's Financial Literacy}

The findings of past studies relating to the methods or education initiatives used to enhance the students' financial literacy were examined in this section. Two studies reviewed both research questions, and 16 studies explored a method to teach financial literacy. Table 3 shows the list of research of effective methods used to enhance financial literacy. Besides, most financial education researches are focusing on secondary school students. The classroom setting seems to be the most common platform to develop financial concepts and skills through inquiry-based learning in mathematics (Blue, O’Brien, \& Makar, 2018; Crawford \& Wiest, 2011), technological simulation (Herlo, 2015; Liu et al., 2011; Schuhen \& Neubauer, 2015; Vidermanova \& Melusova, 2015), and interactive module (Rondillas \& Buan, 2019). However, to ensure a smoother transmission of knowledge and skills, the activity approach does not need to be the preferred tool. Still, it is more effective in the case of learning new terminology (Opletalova, 2017). Besides that, to help increase students' interaction with mathematics, financial literacy tasks must be guided by student interests, authentic, and most important are hands-on experience. For example, Attard (2018) found that students' engagement improved cognitively, operatively, and virtually through financial literacy tasks known as Market Day. Next, Sawatzki (2016) suggested two problem contexts: Catching the bus and Buying bread includes an unfamiliar, novel, and imaginable financial dilemmas that help to broaden students' horizons. Meanwhile, Sawatzki and Goos (2018) observed different responses among students regarding the price of lolly bags for sale as part of fundraising activity.

Table 3. List of researches of effective methods used to enhance financial literacy

\begin{tabular}{llll}
\hline \multirow{2}{*}{$\begin{array}{l}\text { Education } \\
\text { Initiatives }\end{array}$} & \begin{tabular}{l} 
Methods \\
Quantitative \\
\cline { 2 - 4 }
\end{tabular} & $\begin{array}{l}\text { Qualitative } \\
\text { research, } \mathbf{n}=\mathbf{n}=4\end{array}$ & $\begin{array}{l}\text { Mixed } \\
\text { method, } \mathbf{n}=\mathbf{5}\end{array}$ \\
\hline $\begin{array}{l}\text { Inquiry-based } \\
\text { learning }\end{array}$ & & Blue et al. (2018) & Sawatzki (2016) \\
\hline
\end{tabular}


Crawford \& Wiest

Sawatzki \& Goos

(2011)

(2018)

Attard (2018)

Schuhen \& Neubauer (2015)

Herlo (2015)

\begin{tabular}{|c|c|c|c|c|}
\hline \multirow{3}{*}{\multicolumn{2}{|c|}{$\begin{array}{l}\text { Technological } \\
\text { simulation }\end{array}$}} & (2015) & \multicolumn{2}{|l|}{ Herlo (2015) } \\
\hline & & & \multicolumn{2}{|l|}{ Liu et al. (2011) } \\
\hline & & & $\begin{array}{ll}\text { Vidermanova } & \& \\
\text { Melusova }(2015) & \end{array}$ & \\
\hline $\begin{array}{l}\text { Interactive } \\
\text { module }\end{array}$ & & & & $\begin{array}{l}\text { Rondillas \& Buan } \\
\text { (2019) }\end{array}$ \\
\hline \multirow{2}{*}{$\begin{array}{l}\text { Financial } \\
\text { education } \\
\text { programs } \\
\text { course }\end{array}$} & & $\begin{array}{l}\text { Adriaan Kalwij et al. } \\
\text { (2019) }\end{array}$ & $\begin{array}{l}\text { Amagir, } \quad \text { Groot, } \\
\text { Maassen van den } \\
\text { Brink, \& Wilschut } \\
(2019)\end{array}$ & $\begin{array}{l}\text { Supanantaroek, } \\
\text { Lensink, \& Hansen } \\
(2017)\end{array}$ \\
\hline & or & $\begin{array}{l}\text { Bhattacharya, Gill, \& } \\
\text { Stanley (2016) }\end{array}$ & $\begin{array}{l}\text { Hamilton, } \quad \text { Shobe, } \\
\text { Murphy-Erby, \& } \\
\text { Christy (2012) }\end{array}$ & $\begin{array}{l}\text { Dituri, Davidson, \& } \\
\text { Marley-Payne (2019) }\end{array}$ \\
\hline
\end{tabular}

Zhu et al. (2019)

Furthermore, various nonprofit organizations and private institutions, including governments, have responded by consistently promoting and implement financial education programs such as the Aflatoun program (Supanantaroek, Lensink, \& Hansen, 2017) and "Cash for College" of Individual Development Savings Account (IDAs) program (Hamilton et al., 2012). Generally, most quantitative studies measure financial education initiatives' impact using quasi-experimental designs and randomized controlled trial (RCT) experiments. Amagir et al. (2019) conduct a financial education program named "SaveWise" to enhance high school students' financial knowledge and skills, attitudes, self - effectiveness, and economic behavior. It consists of 8 lessons of 50 minutes that focus on learning. The result showed that students have been more motivated to accomplish their target on saving, budgeting, and spending less money. Kalwij et al. (2019) found a 45-minute financial education program in the form of a Cash Quiz game. During Money Week, it is carried out, an annual event that focuses on financially educating children by distributing thematic materials on a wide range of financial topics related to daily experience all primary schools. Besides that, Bhattacharya 
et al. (2016) allowed students to gain financial knowledge through a week of financial fitness camp using the financial curriculum consist of five themes of the Financial Fitness for Life and simulations game known as The Stock Market Game. In contrast, Zhu, Yu, and Chou (2019) conducted ten weekly sessions after school workshops using the primary teaching material: Financial Fitness for Life and Chin Family, which guides the students to make good choices about earning cash, saving, purchasing, investing, borrowing, and handling money. Despite the possible advantages and perceived good intentions of the financial education program, the empirical evidence provides inconsistent results (Carpena, Cole, Shapiro, \& Zia, 2019) and hardly shows any effect (De Witte, Holz, \& De Beckker, 2020) for a long term.

\section{Discussion}

As stated in the empirical analysis of the studies above, financial literacy relies on behavior or financial skills, financial knowledge, and financial socialization. The results based on studies conducted from 2011 until 2019 showed that the factors affecting students' financial literacy were teaching methods and strategies, parental socialization, and school curriculum. It is essential to understand the influence of various factors. Knowing the factors that lead to or detract from acquiring financial literacy among students will improve their economic well-being by making policy initiatives (Garg \& Singh, 2018). Besides that, financial education has become a cognitive approach to facilitate the students' learning process and provide more practical experience in supporting influential learning theories (Berková \& Krpálek, 2017). The financial literacy program may promote positive changes to the students in terms of financial literacy, economic behavior, and financial competency (Kalwij et al., 2019; Amagir, Groot, Maassen van den Brink, \& Wilschut, 2018; Amagir et al., 2019; Zakaria, Sabri, \& Rahim, 2017; Bhattacharya et al., 2016; Supanantaroek et al., 2017). However, the studies measure mainly short-term effects. There is no one-size-fits-all for providing financial education (De Witte et al., 2020; Lusardi, 2019). It should be pivoting and consistently adjust to equip the students with a sense of awareness, adequate comprehension, and confidence to ask the right questions about finances.

Also, financial literacy among teachers should be increased. More attention is needed to convince the teachers of the value of infusing it into their daily lessons to provide adequate financial education. Few studies show that the low competency and conceptual comprehension among teachers affect financial literacy teaching (Björklund, 2019; De Beckker, Compen, De Bock, \& Schelfhout, 2019; De Moor \& Verschetze, 2017; Leumann, 2017). Therefore, the teacher's professional development program has the potential to enhance financial literacy among teachers. De Witte et al. (2020) state a rising awareness regarding teacher development programs rather than a one-shot development phase and attending activities or workshops. Based on the research methodology aspect, most of the questionnaires used in the studies are adapted from PISA OECD (2012) and focuses on the students' knowledge and saving skills, source of income, investment, and spending. Finally, further exploration and theoretical arguments are needed for studies in this field to identify the complexities of integrating financial literacy into the teaching and learning process, particularly for mathematics. 


\section{Conclusion}

The financial world changes very rapidly, and each stage of life entails numerous financial difficulties. Here is where financial literacy comes in to empower informed consumers of financial services. Ultimately, people need to take responsibility for their own financial choices. This review's findings show the integration of financial literacy in education has been gradually increasing, and the teachers' role as agents of social change requires assistance and professional support to develop teachers' self-efficacy. Factors such as teaching methods, school curriculum, and parental socialization must be considered by those responsible for educational policies to formulate effective interventions. Besides that, financial education at an early age may not be the best solution. Still, it has become one of the strategies that offer great potential for future economic well-being among children and youth. However, the implementation must be well adapted to a student's age since children and youth's needs vary from adults.

This systematic review purposely focuses on identifying existing research elements that explore factors influencing financial literacy and effective methods to enhance school students' financial literacy, especially mathematics. We have recognized areas in need of further study by empirically summarising the literature, but our methodology has limitations that need to be addressed. Intentionally, we employed narrow search criteria of studies that were defined by keyword search criteria. Thus, we may not have included studies that integrate financial literacy in school settings and the related current literature. Moreover, we acknowledge the limitations of existing financial literacy assessments for addressing learning objectives involving critical thinking and performance skills to align with the three main learning domains. The effectiveness of the intensity and scope of financial literacy instruction in mathematics is also not adequate. Given these limitations, we recommend that future researchers focus on the current use of technology to support innovative financial task-design and develop rigorous evaluation methodologies to obtain information that can point out the intentional development of financial education programs and strategies for school students.

\section{References}

Aladdin, Y. H., \& Ahmad, A. (2017). Tahap Literasi Kewangan di Kalangan Mahasiswa. International Coference on Global Education V "Global Education, Common Wealth and Cultural Diversity,” (April 2017), 2373-2387. Padang, Indonesia: Universitas Ekasakti.

Amagir, A., Groot, W., Maassen van den Brink, H., \& Wilschut, A. (2018). A review of financial-literacy education programs for children and adolescents. Citizenship, Social and Economics Education, 17(1), 56-80. https://doi.org/10.1177/2047173417719555

Amagir, A., Groot, W., Maassen van den Brink, H., \& Wilschut, A. (2019). SaveWise: The design of a financial education program in The Netherlands. Citizenship, Social and Economics Education, 18(2), 100-120. https://doi.org/10.1177/2047173419870053

Atkinson, A., \& Messy, F.-A. (2012). Measuring Financial Literacy Results of The OECD / International Network on Financial Education (INFE) Pilot Study. In Journal of Consumer Affairs. https://doi.org/10.1111/j.1745-6606.2010.01170.x

Attard, C. (2018). Financial Literacy: Mathematics and Money Improving Student 
Engagement. Australian Primary Mathematics Classroom, 23, 9-12.

Belás, J., Nguyen, A., Smrčka, L., Kolembus, J., \& Cipovová, E. (2016). Financial literacy of secondary school students. Case study from the Czech Republic and Slovakia. Economics and Sociology, 9(4), 191-206. https://doi.org/10.14254/2071-789X.2016/9-4/12

Berková, K., \& Krpálek, P. (2017). Approaches to the development of cognitive process dimensions in financial literacy: An empirical study. Journal of International Studies, 10(3), 173-188. https://doi.org/10.14254/2071-8330.2017/10-3/13

Bhattacharya, R., Gill, A., \& Stanley, D. (2016). The effectiveness of financial literacy instruction: The role of individual development accounts participation and the intensity of instruction. Journal of Financial Counseling and Planning, 27(1), 20-35. https://doi.org/10.1891/1052-3073.27.1.20

Björklund, M. (2019). Teaching financial literacy: Competence, context and strategies among Swedish teachers. Journal of Social Science Education, 18(2), 28-48. https://doi.org/10.4119/ jsse- 1426

Blue, L. E., O’Brien, M., \& Makar, K. (2018). Exploring the classroom practices that may enable a compassionate approach to financial literacy education. Mathematics Education Research Journal, 30(2), 143-164. https://doi.org/10.1007/s13394-017-0223-5

Cameron, M. P., Calderwood, R., Cox, A., Lim, S., \& Yamaoka, M. (2013). Personal financial literacy among high school students in New Zealand, Japan and the USA. Citizenship, Social and Economics Education, 12(3), 200-215. https://doi.org/10.2304/csee.2013.12.3.200

Carpena, F., Cole, S., Shapiro, J., \& Zia, B. (2019). The ABCs of financial education: Experimental evidence on attitudes, behavior, and cognitive biases. Management Science, 65(1), 346-369. https://doi.org/10.1287/mnsc.2017.2819

Chambers, R. G., Asarta, C. J., \& Farley-ripple, E. N. (2019). Gender, Parental Characteristics and Financial Knowledge of High School Students: Evidence From Multicountry Data. Journal of Financial Counseling and Planning, 30(1), 97-109. https://doi.org/10.1891/1052-3073.30.1.97

Crawford-Ferre, H. G., Wiest, L. R., \& Vega, S. (2016). Teaching Middle-Grades Mathematics through Financial Literacy. Kappa Delta Pi Record, 52(2), 79-82. https://doi.org/10.1080/00228958.2016.1156526

Crawford, H., \& Wiest, L. (2011). Business as Usual? Not for These Middle-Grades Students. Australian Primary Mathematics Classroom, 16(1), 4-9.

Darusalam, G., \& Hussin, S. (2018). Metodologi Penyelidikan dalam Pendidikan: Amalan dan Analisis Kajian Edisi Kedua. Penerbit Universiti Malaya.

De Beckker, K., Compen, B., De Bock, D., \& Schelfhout, W. (2019). The capabilities of secondary school teachers to provide financial education. Citizenship, Social and Economics Education, 18(2), 66-81. https://doi.org/10.1177/2047173419850152

De Moor, L., \& Verschetze, L. (2017). Student Teachers' Capacity and Willingness to Teach Financial Literacy in Flanders. Journal of Financial Counseling and Planning, 28(2), 313-321. https://doi.org/10.1891/1052-3073.28.2.313

De Witte, K., Holz, O., \& De Beckker, K. (2020). Financial education: Current practices and 
future challenges. Waxmann Publishing Co.

Dituri, P., Davidson, A., \& Marley-Payne, J. (2019). Combining Financial Education With Mathematics Coursework: Findings From a Pilot Study. Journal of Financial Counseling and Planning, 30(2), 313-322. https://doi.org/10.1891/1052-3073.30.2.313

Erner, C., Goedde-Menke, M., \& Oberste, M. (2016). Financial literacy of high school students: Evidence from Germany. Journal of Economic Education, 47(2), 95-105. https://doi.org/10.1080/00220485.2016.1146102

Ferreira, S. M., \& Bisognin, V. (2020). Construction of mathematical and financial concepts based on realistic mathematics education. Acta Scientiae, 22(5), 226-253. https://doi.org/ 10.17648/acta.scientiae.5925

Garg, N., \& Singh, S. (2018). Financial literacy among youth. International Journal of Social Economics, 45(1), 173-186. https://doi.org/10.1108/IJSE-11-2016-0303

Ghazali, M. S., Azer, I., Mohamad, S. A., Muhamad Arifin, N. A., \& Mat, A. (2017). Personal financial literacy among high school students in Raub Pahang, Malaysia. Journal of Engineering and Applied Sciences, 12(9), 2280-2284. https://doi.org/10.3923/jeasci.2017. 2280.2284

Goyal, K., \& Kumar, S. (2020). Financial literacy: A systematic review and bibliometric analysis. International Journal of Consumer Studies, (April), 1-26. https://doi.org/ 10.1111/ijcs. 12605

Hamilton, L., Shobe, M., Murphy-Erby, Y., \& Christy, K. (2012). "It's all about security to me": The role of environment in youth financial literacy and savings behaviors. SAGE Open, 2(4), 1-8. https://doi.org/10.1177/2158244012471958

Herlo, D. (2015). "Consumer Classroom" European Website, an Interactive Tool for Consumer Education. Procedia - Social and Behavioral Sciences, 180, 1489-1497. https://doi.org/https://doi.org/10.1016/j.sbspro.2015.02.297

Huston, S. J. (2010). Measuring Financial Literacy. Journal of Consumer Affairs, 44(2), 296-316. https://doi.org/10.1111/j.1745-6606.2010.01170.x

Huzaini, B. N. (2019, December 11). 60 peratus muflis adalah golongan muda - Bank Dunia. Berita Harian. Retrieved from https://www.bharian.com.my

Jayaraman, J. D., \& Jambunathan, S. (2018). Financial literacy among high school students: Evidence from India. Citizenship, Social and Economics Education, 17(3), 168-187. https://doi.org/10.1177/2047173418809712

Kaiser, T., \& Menkhoff, L. (2017). Does financial education impact financial literacy and financial behavior, and if so, when? World Bank Economic Review, 31(3), 611-630. https://doi.org/10.1093/wber/lhx018

Kalwij, A, Alessie, R., Dinkova, M., Schonewille, G., van der Schors, A., \& van der Werf, M. (2019). The Effects of Financial Education on Financial Literacy and Savings Behavior: Evidence from a Controlled Field Experiment in Dutch Primary Schools. Journal of Consumer Affairs, 53(3), 699-730. https://doi.org/10.1111/joca.12241

Khan, K. S., Kunz, R., Kleijnen, J., \& Antes, G. (2003). Five steps to conducting a systematic review. Journal of the Royal Society of Medicine, 96(3), 118-121. https://doi.org/10.1258/ 
jrsm.96.3.118

Lahav, E., Shavit, T., \& Benzion, U. (2017). Don't Let Them Fool You: Adolescents' Present-orientation and Inferior Financial Understanding. YOUNG, 26(3), 271-289. https://doi.org/10.1177/1103308817713623

Leumann, S. (2017). Representing Swiss vocational education and training teachers' domain-specific conceptions of financial literacy using concept maps. Citizenship, Social and Economics Education, 16(1), 19-38. https://doi.org/10.1177/2047173416689687

Liu, C., Franklin, T., Shelor, R., Ozercan, S., Reuter, J., Ye, E., \& Moriarty, S. (2011). A Learning Game for Youth Financial Literacy Education in the Teen Grid of Second Life Three-Dimensional Virtual Environment. American Journal of Business Education, 4(7), 1-18. https://doi.org/10.19030/ajbe.v4i7.4670

Lusardi, A. (2019). Financial literacy and the need for financial education: evidence and implications. Swiss Journal of Economics and Statistics, 155(1), 1-8. https://doi.org/10.1186/ s41937-019-0027-5

Magesvari, R., Kenayathulla, H. B., \& Ghani, M. F. A. (2018). Faktor Sosioekonomi Yang Mempengaruhi Kemahiran Literasi Kewangan Pelajar Sekolah Menengah Di Negeri Sembilan. Jurnal Kepimpinan Pendidikan, 5(3), 10-33.

Mahmudi, A., \& Listiyani, D. H. (2019). Analysis of students' financial literacy skills on mathematics teaching and learning. Journal of Physics: Conference Series, 1320(1). https://doi.org/10.1088/1742-6596/1320/1/012044

Mcgregor, S. L. T. (2016). Status of Consumer Education and Financial Education in Canada (2016). Canadian Journal of Education, 2(41), 601-632.

Mokhtar, N., Thinagaran, M. D., Sabri, M. F., \& Ho, C. S. F. (2018). A Preliminary Evaluation of Financial Literacy in Malaysia. Journal of Wealth Management \& Financial Planning, 5(6), 3-16.

Moher, D., Liberati, A., Tetzlaff, J., \& Altman, D. G. (2009). Preferred reporting items for systematic reviews and meta-analyses: The PRISMA statement. BMJ (Online), 339(7716), 332-336. https://doi.org/10.1136/bmj.b2535

Moreno-García, E., García-Santillán, A., \& Gutiérrez, A. D. los S. (2019). Financial literacy of "telebachillerato" students: A study of perception, usefulness and application of financial tools. International Journal of Education and Practice, 7(3), 168-183. https://doi.org/10.18488/journal.61.2019.73.168.183

OECD. (2005). Improving Financial Literacy: Analysis of Issues and Policies. OECD Publishing, Paris. https://doi.org/10.1787/9789264012578-en

OECD. (2013)."Financial Literacy Framework", in PISA 2012 Assessment and Analytical Framework: Mathematics, Reading, Science, Problem Solving and Financial Literacy, OECD Publishing, Paris. https://doi.org/10.1787/9789264190511-7-en

OECD (2017), "What do 15-year-olds really know about money?", PISA in Focus, No. 72, OECD Publishing, Paris. https://doi.org/10.1787/21dc1a9a-en

Opletalova, A. (2017). Financial Literacy In Primary Schools From The Perspective Of Teaching Methods. In Bekirogullari, Z and Minas, MY and Thambusamy, RX (Ed.), 4th 
Icpsirs International Conference On Political Science, International Relations And Sociology (pp. 110-121). https://doi.org/10.15405/epsbs.2017.02.10

Opletalová, A. (2015). Financial Education and Financial Literacy in the Czech Education System. Procedia - Social and Behavioral Sciences, 171, 1176-1184. https://doi.org/ 10.1016/j.sbspro.2015.01.229

Peeters, N., Rijk, K., Soetens, B., Storms, B., \& Hermans, K. (2018). A Systematic Literature Review to Identify Successful Elements for Financial Education and Counseling in Groups. Journal of Consumer Affairs, 52(2), 415-440. https://doi.org/10.1111/joca.12180

Puspitarona, D. S., Abdulhak, I., \& Rusman. (2019). Financial literacy for elementary school students: Case study of Bandung city, Indonesia. International Journal of Learning, Teaching and Educational Research, 18(10), 292-307. https://doi.org/10.26803/IJLTER.18.10.19

Rondillas, F. I., \& Buan, A. T. (2019). Development of an Interactive Module Incorporating Financial Literacy in Teaching Decimals/Fraction. Journal of Physics: Conference Series, 1340(1). https://doi.org/10.1088/1742-6596/1340/1/012049

Sawandi, N., Abu Bakar, A. S., Shaari, H., Saad, R. A., \& Amran, N. A. (2018). Financial literacy among Malaysian: Level of financial knowledge score. Journal of Social Sciences Research, 2018(Special Issue 6), 300-304. https://doi.org/10.32861/jssr.spi6.300.304

Sawatzki, C. (2016). Insights from a financial literacy task designer: The curious case of problem context. In B. White, M. Chinnappan, \& S. Trenholm (Eds.), Opening Up Mathematics Education Research, Proceedings of the $39^{\text {th }}$ Annual Conference of the Mathematics Education Research Group of Australasia (pp. 576-583). Adelaide: MERGA

Sawatzki, C. (2017a). Lessons in financial literacy task design: authentic, imaginable, useful. Mathematics Education Research Journal, 29(1), 25-43. https://doi.org/10.1007/s13394-016 -0184-0

Sawatzki, C. (2017b). Pricing: Exploring the intersection between values, Maths, Finance, and Entrepreneurship. In A. Downton, S. Livy, \& J. Hall (Eds.). 40 Years on: We Are Still Learning!, Proceedings of the 40th Annual Conference of the Mathematics Education Research Group of Australasia (pp. 458-465). Melbourne, Australia: MERGA.

Sawatzki, C., \& Goos, M. (2018). Cost, price, and profit: what influences students' decisions about fundraising? Mathematics Education Research Journal, 30(4), 525-544. https://doi.org/ 10.1007/s13394-018-0241-y

Schuhen, M., \& Neubauer, M. (2015). Economic education via consumer advice programmes? Informal learning based on the example of the television help format 'Out of Debt.' Citizenship, Social and Economics Education, 14(3), 193-202. https://doi.org/10.1177/ 2047173416630014

Silva, T. P. da, Magro, C. B. D., Gorla, M. C., \& Nakamura, W. T. (2017). Financial education level of high school students and its economic reflections. Revista de Administração, 52(3), 285-303. https://doi.org/10.1016/j.rausp.2016.12.010

Snyder, H. (2019). Literature review as a research methodology: An overview and guidelines. Journal of Business Research, 104(August), 333-339. https://doi.org/10.1016/ j.jbusres.2019.07.039 


\section{Macrothink}

International Research in Education

ISSN 2327-5499

2021, Vol. 9, No. 1

Solomon, G. E., Nhete, T., \& Sithole, B. M. (2018). The Case for the Need for Personal Financial Literacy Education in Botswana Secondary Schools. SAGE Open, 8(1), 1-9. https://doi.org/10.1177/2158244017753867

Soroko, A. (2020). Buying into dominant ideas about wealth and poverty: An examination of U.S. and Canadian financial literacy standards. Teachers College Record, 122(3).

Supanantaroek, S, Lensink, R., \& Hansen, N. (2017). The Impact of Social and Financial Education on Savings Attitudes and Behavior Among Primary School Children in Uganda. Evaluation Review, 41(6), 511-541. https://doi.org/10.1177/0193841X16665719

Swiecka, B., Yeşildağ, E., Özen, E., \& Grima, S. (2020). Financial literacy: The case of Poland. Sustainability (Switzerland), 12(2), 1-17. https://doi.org/10.3390/su12020700

Vidermanova, K., \& Melusova, J. (2015). The Visualization of the Schedule of the Mortgage Loan as a Tool for Students' Better Understanding of Loans. Procedia - Social and Behavioral Sciences, 186, 1224-1231. https://doi.org/https://doi.org/10.1016/j.sbspro. 2015.04.145

Wahab, R., Sabri, M. F., \& Ramli, N. N. (2016). Money Literacy, Shopping and Purchasing Patterns among Primary School Students in Malaysia. Journal of Education and Human Development, 5(1), 146-162. https://doi.org/10.15640/jehd.v5n1a16

Yakob, R., Janor, H., \& Khamis, N. A. (2015). Tahap Literasi Kewangan dalam Kalangan Pelajar Universiti Awam: Kajian di Universiti Kebangsaan Malaysia. Jurnal Personalia Pelajar, 13(3), 1576-1580.

Zakaria, N. L, Sabri, M. F., \& Rahim, H. A. (2017). Penilaian Impak Program Pendidikan Program Bijak Wang. Jurnal Pengguna Malaysia, 29, 19-38.

Zhu, A. Y. F., Yu, C. W. M., \& Chou, K. L. (2019). Improving Financial Literacy in Secondary School Students: An Randomized Experiment. Youth and Society, 1-24. https://doi.org/10.1177/0044118X19851311

\section{Copyright Disclaimer}

Copyright reserved by the authors.

This article is an open-access article distributed under the terms and conditions of the Creative Commons Attribution license (http://creativecommons.org/licenses/by/4.0/). 